\title{
THE CONCEPT OF NATIONAL LAW AND THE RULE OF RECOGNITION
}

\author{
MELVIN A. EISENBERG ${ }^{\star}$
}

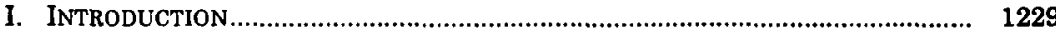

II. THE CONCEPT OF NATIONAL LAW ............................................................. 1232

A. Local Law, Federal Law, and National Law ........................................ 1232

B. The Economic Element .......................................................................... 1235

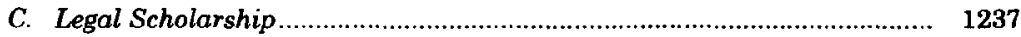

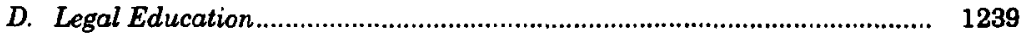

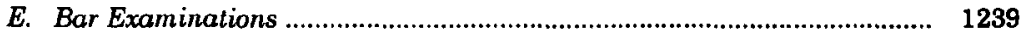

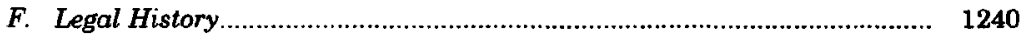

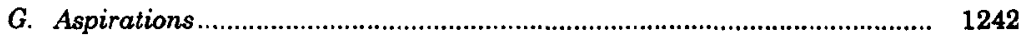

III. Four PRINCIPLES CONCERNING THE CONCEPT OF THE RULE OF ReCognition 1243

A. The Social Group That Must Accept a Secondary Rule for the Rule to Constitute a Rule of Recognition is the Legal Profession, Rather Than Simply Judges and Other Officials ..

B. Whether the Legal Profession Accepts a Secondary Rule as a Rule of Recognition Can Be Determined By Examining the Kinds Of Primary Rules That Are Invoked by the Profession as Legal Rules in Resolving Legal Issues in General, and Deciding Cases in Particular.

C. A Rule Can Be a Legal Rule Even Though it is Not Binding

D. In the United States, Law is Made Not Only by Judges and Other Officials of the Deciding Jurisdiction, but Also by the National Judiciary, Legal Scholars, and Professional Institutions.

\section{INTRODUCTION}

It is a commonly held position that a rule cannot be a legal rule unless the rule is binding; or to put it differently, that one element that distinguishes legal rules from other kinds of rules is that legal rules are regarded as binding by duly constituted officials-typically, courts-who are called upon to apply them. ${ }^{1}$ Thus in addressing the issue whether international law is law, H.L.A. Hart stated that 'if . . . the rules of international law are not 'binding,' it is surely indefensible to take seriously their classifications as law; for however tolerant the modes of common speech may be, this is too great a difference to be overlooked." Similarily, Joseph Raz draws a central distinction between "regulated" and "unregulated" disputes: a dis-

* Koret Professor of Law, University of California at Berkeley. A.B., Columbia College, 1956; LL.B., Harvard Law School, 1959.

An earlier version of this Article was presented as the Mason Ladd Lecture at Florida State University College of Law in 1997. I thank Meier Dan-Cohen, Mark Greenberg, Kent Greenawalt, Ken Kress, Chris Kutz, and Robert Post for their exceptionally valuable com. ments on earlier drafts of this Article, and Jon Eldan and Bhavna Daryanani for their very helpful work as research assistants. dards.

1. Through this Article I use the term "rule" to include rules, principles, and stan-

2. H.L.A. HART, THE CONCEPT OF LAW 217 (2d ed. 1994). 
pute is "regulated," for Raz, if "the law is clear and cannot be changed by the judicial organ." In regulated disputes, one particular solution is required by law; the court decides the case by applying preexisting and legally binding rules that it is under a duty to apply. ${ }^{4}$ All other disputes are "unregulated."

Similarly, it is an often-held position that the law consists of the rules of a jurisdiction that are duly enacted or adopted by officials who have the power to make rules that are binding in the jurisdiction. So, for example, Raz states: "We find our law in statute books and law reports. ... [L]aws ... can be enacted or repealed by legislatures and administrative authorities. They can also become legally binding through establishment by the courts." 5

The thesis of this Article is that both positions are incorrect.

To demonstrate that thesis I will begin, in Part II, by developing a concept that I call national law. The concept of national law is that there is a body of law in the United States that is made by officials across jurisdictions, legal scholars, and scholarly institutions, which constitutes law despite the fact that it is not binding in, and is not necessarily made by, officials of a deciding jurisdiction. Examples of national law are the rules that a donative promise is enforceable if relied upon, that an acceptance is effective on dispatch, and that the remedy for breach of a bargain contract is expectation damages. $\mathrm{Na}$ tional law is law because, as I will show, under the practice of the legal profession, particularly the courts, the rules of national law (and not simply, or not at all, the reasons for those rules) are invoked as legal rules of decision.

Next, in Part III, I will consider certain aspects of the concept of the rule of recognition, formulated by H.L.A. Hart. ${ }^{6}$ Under that concept, a critical distinction is drawn between primary rules and secondary rules. Primary rules are rules of obligation that state how people are obligated to behave. ${ }^{7}$ Secondary rules are rules about establishing, changing, and applying primary rules. "They specify the ways in which the primary rules may be conclusively

3. JOSEPH RAZ, THE AUTHORITY OF LAW 172 (1979).

4. Id. at $71,90,96,181$.

5. Joseph Raz, Legal Principles and the Limits of Law, 81 YALE L.J. 823, 825, 848 (1972). There is a bit of dissonance within positivism, on this issue, concerning the status of custom as law. Raz takes the position that "[e]ven legal custom is not law until it is recognized and declared to be law by the courts." RAZ, supra note 3 , at 87. In contrast, H.L.A. Hart took the position that a custom could be law even before it was recognized as law by the courts, although he admitted that the kind of claim Raz makes may have "some plausibility." HART, supra note 2 , at 44-48, 64. In any event, this dissonance is today marginal if not scholastic. Whether custom is law was chiefly salient in the matter of feudal tenures. The likelihood that the issue would arise in the context of a contemporary legal problem is highly remote in the United States, and probably in England as well.

6. HART, supra note 2, at 80-81, 94-95, 99, 107, 109.

7. Id. at $80-81$. 
ascertained, introduced, eliminated, varied, and the fact of their violation conclusively determined." ${ }^{3}$ The most fundamental type of secondary rule is a rule of recognition. A rule of recognition is a rule that tells how to recognize that some other rule is a legal rule. As the rule of recognition is commonly understood, a given rule is a valid legal rule if but only if its pedigree can ultimately be traced to a source that is a source of law under a rule of recognition. ${ }^{9}$ In contrast, a given rule is a rule of recognition if but only if it is accepted by the society, and perhaps more particularly by its officials.

In this Article I will take the concept of a rule of recognition as a postulate, and develop the following four principles concerning the meaning, application, and scope of that concept:

(1) The social group that must accept a secondary rule for the rule to constitute a rule of recognition is the legal profession, rather than simply judges and other officials.

(2) Whether the legal profession accepts a rule as a secondary rule of recognition can be determined by examining the kinds of primary rules that are invoked by the profession as legal rules in resolving legal issues in general, and deciding cases in particular.

(3) A rule can be a legal rule even though it is not binding.

(4) In the United States, law is made not only by judges and other officials of the deciding jurisdiction but also by the national judiciary, legal scholars, and professional institutions (in particular, the American Law Institute).

These four principles and the concept of national law are separate but intimately related. They are separate because the concept of national law and the four principles can each stand on its own. They are intimately related because, on the one hand, the legal status of national law is one of its most important characteristics, while on the other hand, national law is a leading although not exclusive exemplar of the principles. Because the principles and the concept are intimately related, a complete account of each depends on the development of the other. I will begin with the concept of national law, next turn to the principles, and finally link the concept and the principles.

8. Id. at 94.

9. See, e.g., RAZ, supra note 3, at 91 (stating that "the rule of recognition of a system constitutes its criterion of validity"). 


\section{THE CONCEPT OF NATIONAL LAW}

\section{A. Local Law, Federal Law, and National Law}

Under the concept of law that underlies some strands of positivism, American law consists of either the law of a state (including a subdivision of the state), which results from the promulgation of legal rules by official organs (including judicial organs) of that state, or of federal law, which results from the promulgation of legal rules by official federal organs. I will refer to statements of rules in those two types of law as statements of local law and statements of federal law, respectively.

By statements of local law, I mean statements that take the express or implied form, "Based on authoritative sources, it is a rule of state $S$ (or of a subdivision of a state, like a city or county) or of states $S, T$, and $U$, that R." Examples include, "Under the law of New York, contracts require consideration," and "Under the law of Pennsylvania, an acceptance is effective on dispatch." By local law, I mean the body of rules of a given state that is described or set out in all such statements that are true. (I use the term local law, rather than state law, because the latter term is often used to refer to any substantive body of law that is not federal law-for example, the law of torts-rather than to the law of a particular state.)

By statements of federal law, I mean statements that take the express or implied form, "Based on authoritative sources, it is a rule of federal law that R." Examples include, "A federal statute prohibits certain kinds of labeling on alcoholic beverages" and "Free speech is guaranteed under the U.S. Constitution." By federal law, I mean the body of rules that is described or set out in all such statements that are true.

Local and federal law might seem to exhaust the categories of domestic law in the United States. If, however, you walk into almost any law school in America, or read almost any leading American treatise or law review, you will find that many of the statements that are made of and about law are neither statements of federal law nor statements of local law. Rather, they are statements of and about law in general terms, divorced from particular jurisdictions. And these kinds of statements are not limited to the scholarly enterprise. Practicing lawyers will often talk in just this way. Perhaps more telling, bar examinations-the gateways to legal practice-are often cast in just this way.

A striking aspect of this kind of legal discourse is that it is so fundamental and so ingrained that those who use it are scarcely conscious, if they are conscious at all, that they are doing something that might seem relatively unusual from the perspective of prevailing le- 
gal theory. Like Molière's bourgeois gentleman, who did not realize that he was speaking "prose,"10 the American legal community does not realize, or realizes in only a limited way, that its everyday discourse reflects an unspoken fundamental premise about law that is in need of exposition, explanation, and examination.

To begin with, then, it is necessary to name this mode of legal discourse, and the name I will give it is statements of national law. By statements of national law, I mean statements, made in the context of the American legal system, that expressly or impliedly take the form "Rule $R$ is law" but are not expressly or impliedly statements that Rule $\mathrm{R}$ is federal or local law. Examples are "contracts require consideration" and "an acceptance is effective on dispatch," where the speaker is not implicitly referring to the law of a given jurisdiction. By national law, I mean the body of rules described or set out in such statements that are established as legal rules in the national legal discourse. (I will expand on this definition in Part III.B.)

A significant portion of national law concerns common law areas, but national law and common law are not coextensive. Some common law areas may not be part of national law because the legal rules in the areas are highly localized. Conversely, even some areas that are basically statutory may be national law in part. This is most obviously the case where a common law rule has been widely codified (as in the case of the rule that only persons who were shareholders at the time of a wrong can bring derivative actions) or where a statutory rule has been ingrained in the law of virtually every state (as in the case of the Statute of Frauds).

In its purest form, a statement of national law may be unaccompanied by supporting citations to given jurisdictions. However, even a statement of a legal rule that is accompanied by such supporting citations may be a statement of national law, where the claim of the statement outruns the citations that could be mustered in its support. The claim in such a statement is categorical, like "death revokes an offer," but the actual citations will typically be limited to cases from only a limited number of jurisdictions, and even the possible citations will be limited to cases from less than all jurisdictions. Accordingly, even when such a statement is accompanied by citations to a number of jurisdictions, it is seldom if ever implied that every jurisdiction has adopted the rule. On the contrary, legal rules are commonly stated in categorical terms even though many jurisdictions have never ruled on the issue. The addressees of such statements are normally supposed to infer, not that the stated rule is the law only of the jurisdictions whose decisions are cited, but that it is a rule of na-

10. MOLIÈRE, THE BouRgEOIS GeNTLEMAN act 2, sc. 4. 
tional law that draws support from cases in the cited jurisdictions, among other things.

In fact, it is not even unusual for a rule to be categorically stated as law in sources that the legal profession views as authoritative although the rule has been adopted only by the courts of a few jurisdictions. To illustrate, there is a well-accepted rule of contract law that where an offer is made in a face-to-face or telephonic conversation, the offer lapses at the end of the conversation unless a contrary intention is indicated. This rule was stated, for example, in Williston's treatise when it was first published in the $1920 \mathrm{~s}^{11}$ and in Corbin's treatise when it was published in the $1950 \mathrm{~s}^{12}$ It is stated as well in the Restatement (Second) of Contracts and in various modern treatises, including the current versions of Williston and Corbin. ${ }^{13}$ As originally published, the Williston treatise cited just two cases in support of the rule. ${ }^{14}$ The Corbin treatise cited no cases at all. Even today, the two treatises, taken together, cite only three additional cases. ${ }^{15}$ Of the five total cited cases, some are not really on point, although they contain dicta that support the rule. Those that are on point are ambiguous. ${ }^{16}$ Many other well-established rules of "contract law"-that is, national contract law-also have extremely limited support in relevant binding precedent. For example, Farnsworth points out that:

Under the original draft of the first Restatement [of Contracts], as written by Williston and his advisers, the unknown death of the of-

11. 1 SAMUel Williston, THE LAW OF ConTraCTS $\$ 54$, at 91 (1st ed. 1920).

12. 1 ARTHur Linton Corbin, Corbin on ConTracts $\S 36$, at 150-51 (1950).

13. See Restatement (SEcond) of ConTracts § 41(1) (1981); John D. CalamaRi \& Joseph M. PERILlo, Contracts § 2-20, at 92-93 (3d ed. 1987); 1 ARTHUR LINTON CORBIN, CORBIN ON CONTRACTS $\S 2.16$ (Joseph M. Perillo ed., rev. ed. 1993); E. ALLAN

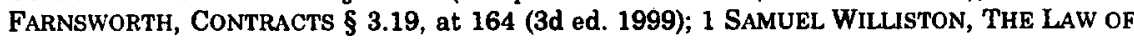
CONTRACTS $\S 5: 7$, at 660 (Richard A. Lord ed., 4th ed. 1990).

14. WILLISTON, supra note 11 , at 92 \& n.33 (citing Mactier's Adm'rs v. Frith, 6 Wend. 103 (N.Y. 1830); Vincent v. Woodland Oil Co., 30 A. 991 (Pa. 1895)).

15. CoRBIN, supra note 13, § 2.16 at 207 \& n.7 (citing Akers v. J.B. Sedberry, Inc., 286 S.W.2d 617 (Tenn. Ct. App. 1955)); WiLliston, supra note 13, § 5:7, at 660 \& n.1 (citing Wagenvoord Broad. Co. v. Canal Automatic Transmission Serv., Inc., 176 So. 2d 188 (La. Ct. App. 1965); Textron, Inc. v. Froelich, 302 A.2d 426 (Pa. Super. Ct. 1973); Akers, 286 S.W.2d 617)).

16. For example, in Akers, the court held that an offer made in a conversation lapsed at the end of the conversation but added that in any event the offer had been rejected even before the conversation ended. Akers, 286 S.W.2d at 621-22. In Textron, a fabricator of steel and wire products orally offered a steel broker specified quantities of two different sizes of steel rods at specified prices. $302 \mathrm{~A} .2 \mathrm{~d}$ at 427 . The broker responded that he thought he wanted the rods but wished to check with his customers. Five weeks later, the broker called the fabricator and agreed to buy one size of rods at the price originally discussed; two days later, he agreed to purchase the other size, again at the earlier specified price. The broker refused to perform on the ground that no contract had been formed, and the fabricator brought suit. The Pennsylvania Superior Court strongly suggested that the conversation norm is only a rule of thumb. Id. 
feror did not revoke [an] offer. But the Council of the American Law Institute changed the statement of the rule so that it does. Williston conceded, concluding that "though the amount of actual authority is not impressive, there is a very general opinion among lawyers that death, even though unknown, does revoke an offer and does revoke an agency."17

In the balance of this Part, I consider some of the reasons why national law exists. I will return to that issue at the end of Part III.

\section{B. The Economic Element}

The economic reason for national law is straightforward: it often is economically desirable to have uniformity of law throughout the country, and national law is an instrument-often the best instrument-for achieving that end.

I begin with a few definitions and distinctions, starting with the term uniformity of law. There are two different concepts of the uniformity of law: uniformity of legal rules, and uniformity of legal results. In this Article I will focus on uniformity of legal rules. For one thing, uniformity of legal rules is what is usually meant when we talk about the uniformity of law. For another, uniformity of legal rules achieves predictability and facilitates coordination in a way that uniformity of legal results does not.

Next, I distinguish between mandatory and nonmandatory unification. By mandatory unification, I mean political processes by which different legal rules of separate jurisdictions are mandatorily replaced, or required to be replaced, by a uniform rule. One such process is entry into a treaty under which a supranational authority is empowered to require national states to adopt uniform legal rules in certain areas. Another is the merger of sovereign states to form a new federal state in which some legal rules, the federal rules, will be mandatorily made uniform, although others, the state rules, will not. By nonmandatory unification, I mean political or social processes, other than mandatory unification, that lead to uniformity in the legal rules of separate jurisdictions.

In the United States, federal law normally originates as uniform law, in the form of constitutional, statutory, or administrative rules. Where conflicts develop in interpreting these rules, the Supreme Court has the power to unify the law, and commonly does so.

Unification of the local law of two or more states presents a more difficult problem. One mode of unifying a state-law area of law is to comprehensively federalize the area. From the perspective of the states, this mode involves mandatory unification. A second mode is

17. FARNSWORTH, supra note $13, \S 3.18$ at 161 . 
state-by-state adoption of uniform acts. A third mode is the development of national law. Both of the latter two modes involve nonmandatory unification.

Federalization and the adoption of uniform acts have the advantages and disadvantages associated with codification and specialinterest lobbying. Uniform acts also have the special disadvantage that they are often not universally adopted. Federalization has the special disadvantage that it tends to put a damper on local experimentation.

In contrast, national law is a mode of achieving uniformity of law without special-interest lobbying, while avoiding codification and therefore preserving flexibility. This is not to say that national law is a better technique to achieve uniformity than federalization or the adoption of uniform acts, only that it may be better in a given case. In any event, the fact is that national law has been a fundamental mode of unification in the United States. Very important bodies of law, such as contracts, agency, and torts, have been made uniform either in significant part or almost in whole largely through this mode. In those areas in which uniformity of law is desirable, and national law is a better instrument for achieving uniformity of law than uniform acts or federalization, national law serves an important economic purpose.

However, although economics may be a reason for uniform law, it is not in itself sufficient. After all, it would also be economically advantageous to have uniform contract law throughout North America, but that has not occurred. It would be economically advantageous to have uniform contract law throughout Europe, but even today the realization of that objective is in a stage of infancy.

Perhaps most telling, in this regard, is the case of Louisiana. If economics alone drove uniform law for forty-nine states, surely it would also drive unification for the fiftieth. It has not. Louisiana was governed by either French or Spanish law from its early beginnings until the Louisiana Purchase. ${ }^{18}$ In 1804 , the Territory of Orleans, later to become the State of Louisiana, was carved out of the Purchase. ${ }^{19}$ Subsequently, the Territorial Legislature, after a vigorous battle with the Territory's civil governor, adopted civil law as the law of the Territory. ${ }^{20}$ Eventually the Legislature adopted a Civil Code. ${ }^{21}$ Shael Herman describes the present legal regime in Louisiana as follows:

18. LAWRENCE M. FRIEDMAN, A HISTORY OF AMERICAN LAW 171 (2d ed. 1985).

19. Shael Herman, The Louisiana Civil CODE 29 (1993).

20. FrIEDMAN, supra note 18 , at 172-73.

21. See id. at 174. 
The Louisiana Civil Code, a one-volume blue-print for society, is among the most significant landmarks in American legal history. Inspired by the continental Roman tradition rather than by English law, the Civil Code makes Louisiana a unique American jurisdiction. Louisiana law, because it bears the imprint of Roman, Spanish, and French law, forces local lawyers to conceive legal issues differently than their counterparts elsewhere in the United States....

Civilians are proud of their scholarship, their intellectual cultivation, and their ability to read law in foreign languages. The Civil Code is the raison d'etre of civilian research. Civilians know French thinkers like Descartes and Rousseau as well as English philosophers like Locke and Hobbes. The doctrinal works of Jean Domat and Robert Pothier are as important for understanding the Civil Code as James Madison's Federalist Papers are for the United States Constitution.

... Louisiana's private law ... today remains almost as different from the rest of American law as the metric system is from the English system of measurement. ${ }^{22}$

Therefore, as important as the economic element is in explaining the existence of national law, other institutional elements must also be at play.

\section{Legal Scholarship}

One of these institutional elements is the nature of American legal scholarship. It is only a slight oversimplification to say that most prestigious legal scholars devote most of their domestic scholarship (that is, scholarship that does not involve comparative or international law) to either pure theory, federal law, or national law. ${ }^{23}$ As a corollary, virtually all the nonfederal, non-pure-theory domestic legal scholarship that is widely admired, and widely familiar to scholars, judges, and practitioners, takes the form of national law. Highprestige scholarship on legal subjects that are basically matters of nonfederal law, like contracts, torts, or agency, only seldom focuses on the law of individual states.

Why should this be so? One reason is that the American scholarly community tends to award recognition and prestige to theoretical and normative work, as opposed to descriptive and positive work. In principle, it may be as easy to do theoretical and normative analysis of local law as of national law. In practice, however, this tends not to be the case. Generally speaking, consumers of work on local law are interested primarily, and often almost exclusively, in descriptive and

22. HERMAN, supra note 19 , at 1-2.

23. My point here of course is not that local-law scholarship is either less worthy or less important than national-law scholarship, but only that for better or for worse as a sociological matter it carries less prestige. 
positive analysis. Typically, therefore, scholars who work on local law must pitch their scholarship in descriptive and positive terms if they are to have an audience.

Furthermore, as a practical matter it is often easier to analyze national law in theoretical and normative terms than to analyze local law in this manner. The spread of legal data points on the national landscape invites a creative integration of the points into a clear line. The process of creative integration, in turn, invites a theoretical and normative enterprise. The lesser number of data points in local law works in the opposite direction. ${ }^{24}$ Furthermore, once the prestige system starts, it is self-perpetuating. Because recognition and prestige goes to scholars who work on pure theory, federal law, comparative law, international law, and national law, scholars who seek recognition and prestige will gravitate toward these fields rather than to local law.

Even apart from issues of recognition and prestige, a scholar who wants to generalize and theorize, as most scholars do, will typically prefer national law over local law because national-law data provides a richer source for generalization and the construction of theories.

There is also an issue of audience. The audience for pure theory, federal law, and national law is nationwide. In contrast, the audience for local law is largely confined to the members of the legal community of a single state and those members of the profession outside that state who happen to have an interest in the law of the state. Accordingly, even apart from the issue of recognition and prestige, scholars who believe they have something important to say, as most scholars do, will often prefer to write about national law rather than local law, because work in national law will allow them to address the widest possible audience.

24. I do not deny that scholars can and do write about local law in a theoretical and normative way. For example, among the best treatises in the area of corporation law are the Marsh treatise on California law and the Balotti and Finkelstein treatise on Delaware corporation law. See generally R. FrankiIN BALOTTI \& JESSE A. FinkELsteIN, THE DELAWARE LAW OF CORPORATIONS AND BUSINESS ORGANIZATIONS (3d ed. 1997); HAROLD MARSh, MARSH's CaLIFornia CoRPoration LAW (4th ed. 2000). I often consult these treatises to gain illumination into general issues of corporation law. I am pretty confident, however, that the vast majority of those who consult these treatises do not use them for general illumination, because their only interest is in the positive and descriptive discussion in the treatises.

Furthermore, the special nature of these treatises may be partly a function of the special nature of Delaware and California corporation law. Delaware corporation law is virtually national corporation law. California is large, populous, and wealthy; it includes within its borders several great commercial centers and highly diverse forms of economic activity; and it has a number of intermediate courts of appeal that are not bound by each other's decisions. As a result, California offers a much richer source of legal data points than do most other states. 


\section{Legal Education}

Legal education is perhaps even more important than legal scholarship as a force for national law in the United States. In domesticlaw areas, all the leading law schools in the United States-and probably the bulk of all the law schools-offer substantive courses that exclusively, or almost exclusively, concern federal law, national law, international law, or pure theory. Correspondingly, all or virtually all leading domestic-law casebooks in the United States that are not federal-law casebooks are national-law casebooks.

These two elements-national-law courses and national-law casebooks-are related both to each other and to the elements that influence legal scholarship. Casebooks are a form of scholarship, and the factors that lead to writing national-law treatises, monographs, and articles also lead to writing national-law casebooks. Writing a casebook oriented to local law would also severely restrict the market for the casebook. In addition, the leading law schools in the United States aspire to be, and hold themselves out to be, national schools with national student bodies. Teaching local law, which would be useful only in the state in which the law school was located, would be inconsistent with this aspiration. What is true of the leading law schools is true of most law schools, because most law schools consider themselves to be, aspire to be, or emulate leading law schools.

A telling aspect of the national-law character of American legal education is the irrelevance of the state in which a legal academic has received her legal education and passed the bar. If the Dean of, say, the University of Michigan Law School was asked whether a candidate for the Michigan faculty was disqualified for an appointment because she had been educated at Columbia Law School and had been admitted to practice only in New York, the Dean would think that the questioner must be from another country, if not another planet.

\section{E. Bar Examinations}

Just as legal scholarship and legal education focus on national law, so too do the bar examinations of most states, in whole or in part. The significant national-law orientation of state bar examinations reinforces the importance of national law. It also provides support to teaching national law, because it relieves law schools from some or all of the pressure to teach local law that could exist if the bar examinations were exclusively oriented to local law. 


\section{F. Legal History}

Another critical element in the development of American national law lies in American legal history. Generally speaking, English common law was officially or unofficially made the law of the early states. Speaking of the period up to the beginning of the nineteenth century, Lawrence Friedman has said:

As a practical matter, English law continued to be used by lawyers and courts, throughout the period, throughout the country. England remained the basic source of all law that was not strictly new or strictly American. The habits of a lifetime were not easily thrown over .... Indigenous legal literature was weak and derivative. There was no general habit of publishing American decisions; American case reports were not common until a generation or more after Independence. To common-law lawyers, a shortage of cases was crippling. To fill the gap, English materials were used, English reports cited, English judges quoted as authority. In the first generation, more English than American cases were cited in American reports. Ordinary lawyers referred to Blackstone constantly; they used his book as a shortcut to the law; and Blackstone was English to the core. ${ }^{25}$

With the exception of Louisiana, the later states followed the early states, one way or another. Arthur Rosett has pointed out that "[m]any western states were devoid of elaborate legal systems until English law arrived with the first pioneers. [Indeed,] Spanish law was shoved aside in the southwest and California despite treaty obligations to respect it." ${ }^{26}$

This common origin of American state law has three kinds of effects. First, state-law doctrines were all born of the same parent concepts, and to the extent that different states developed different doctrines, the doctrines are more likely to resemble fraternal twins than members of different families. Second, Americans were trained from the beginning to think that they had a national law-that is, at the beginning, English law. Third, as a result of this history, together with their subsequent legal education, American lawyers have a common vocabulary and a common doctrinal base.

The significance of history is brought home by the experience in Louisiana, whose early law was based on civil rather than English law, and whose law even today remains outside the boundaries of national law.

25. Friedman, supra note 18 , at 112

26. Arthur Rosett, Unification, Harmonization, Restatement, Codification, and Reform in International Commercial Law, 40 AM. J. CoMP. LAW 683, 695 (1992); see also FrIEDMAN, supra note 18, at 167-72. 
Another body of law that is historically relevant to national law is one that is now almost forgotten: the "general law" of the early nineteenth century. Willy Fletcher has recaptured this almost forgotten body of law:

A modern reader may find it hard to understand the concept of general law employed by early nineteenth century lawyers and judges. The underlying premise was that the general law was not attached to any particular sovereign; rather, it existed by common practice and consent among a number of sovereigns. The group of relevant participants in the law-making and law-determining process varied depending on the category of general law at issue. ... The American courts resorted to this general body of preexisting law to provide the rules of decision in particular cases without insisting that the law be attached to any particular sovereign.

During the first part of the nineteenth century, the federal courts often used ... general law to supply the rule of decision. It was applied in a wide variety of cases, but most frequently and consistently in commercial cases. As an article of faith, and as a matter of substantial truth, jurisprudential writers from the middle of the eighteenth through the early nineteenth century reiterated that commercial transactions in all civilized trading countries were governed by a uniform set of commercial laws ....

The concept of a uniform law merchant was quite naturally imported into the treatment of commercial law by American courts. Justice James Wilson, in his Lectures on Law delivered in 1790 and 1791 in Philadelphia, referred to the law merchant as having "been admitted to decide controversies concerning bills of exchange, policies of insurance, and other mercantile transactions, both where citizens of different states, and where citizens of the same state only, have been interested in the event." . . Zephaniah Swift, justice and later chief justice of the Connecticut Supreme Court, wrote in his 1810 digest of the law of evidence and treatise on negotiable instruments, "In questions of commercial law, the decisions of Courts, in all civilized, and commercial nations, are to be regarded, for the purpose of establishing uniform principles in the commercial world." ...

The sense of adhering to and applying a "universal law" of commercial transactions persisted, to some degree, throughout the first half of the nineteenth century; but as early as 1810 , it began to be supplanted by the notion of a uniquely American common law. By the 1820's, a new pride in American law had emerged and American lawyers began to speak fairly regularly of a distinctly American law merchant, different in significant respects from the international law merchant. 
This modified law merchant was still regarded as a general American common law rather than as the local law of any particular state. . . . ${ }^{27}$

The long reign of general law, which undoubtedly drew in part from the older American habit of following English law, reinforced the American norm that legal rules did not have to be either local or federal. And although general law itself withered away under the influence of Erie $v$. Tomkins, ${ }^{28}$ historically it served as a kind of template for national law, which is in some important ways its successor.

\section{G. Aspirations}

National law is also the product of a cultural aspiration to be an American nation with an American culture and an American law. The Louisiana experience tells much about the importance that a culture places on its law. When the Governor of the Territory that later became Louisiana attempted to force the Territory to adopt common law, the citizens of the Territory saw this attempt as a threat to the fundamental nature of their culture. In a manifesto, the President of the Territory's legislative council and other legislators protested:

We certainly do not attempt to draw any parallel between the civil law and the common law; but, in short, the wisdom of the civil law is recognized by all Europe; and this law is the one which nineteen-twentieths of the population of Louisiana know and are accustomed to from childhood, of which they would not see themselves deprived without falling into despair. If the inhabitants of this Territory had never known any laws, if they had lived down to the present time without making agreements or contracts, it would perhaps be a matter of indifference to them whether to adopt one system or another system, and it is even probable that their attachment to their new mother country would cause them to prefer that system which would bring them nearest to their new fellowcitizens. But it is a question here of overthrowing received and generally known usages, and the uncertainty with which they would be replaced would be as unjust as disheartening. ${ }^{29}$

Just as the citizens of the Territory that became Louisiana wanted a law that reflected their outlook on the world, so do the citizens of America as a whole. In the long run, legal rules can only be justified by propositions of morality, policy, and experience. It is true

27. William A. Fletcher, The General Common Law and Section 34 of the Judiciary Act of 1789: The Example of Marine Insurance, 97 HARV. L. REV. 1513, 1517-20 (1984) (footnotes omitted).

28. 304 U.S. 64 (1938).

29. Manifesto of Legislative Council of Territory of Orleans (1806), reprinted in HERMAN, supra note 19, at 29.30. 
that a person or an official may be justified in following or adhering to a legal rule, without regard to such propositions, on the basis of the source of the rule; but what counts as a justification for following or adhering to a rule is different from what counts as a justification of the rule itself. Thus if there is a legal rule that a simple unreliedupon donative promise is unenforceable, and a promisee brings suit on such a promise, a court could justify holding for the promisor on the ground that this result was required by the established rule. However, that justification of the court's decision would do nothing to show that the rule was itself justified. Similarly, if the Statute of Frauds is in effect in a given jurisdiction, and a promisee brings suit on an oral contract for the sale of land, a court could justify holding for the promisor on the ground that the Statute of Frauds barred the suit. Again, however, that justification of the court's decision would do nothing to show that the Statute of Frauds was itself justified. The rules concerning the unenforceability of simple unrelied-upon donative promises and oral contracts for the sale of land can be justified, if at all, only on the basis of morality, policy, and experience.

In the common law areas that form the great bulk of national law, the ultimate justifications of legal rules normally must be found in social morality and social policy. Social morality and social policy vary locally to a certain extent, but at least in the areas that are the subject of national law, they tend to be American rather than local. The concept that otherwise-equivalent transactions can properly be given different treatment simply because they occur on different sides of a state boundary is only infrequently supported in the present day. We are, after all, one country.

\section{Four PRINCIPLES CONCERNING THE CONCEPT OF THE RULE OF RECOGNITION}

To recapitulate, there are a number of rules in the United States that are not binding and are not promulgated by official organs of a relevant jurisdiction, but which are generally accepted as legal rules. I call the body of these rules national law. When law school teachers teach domestic nonfederal law, they commonly or indeed usually teach national law. When legal scholars write about domestic nonfederal law, they commonly or indeed usually write about national law. For example, when we teach that a contract requires consideration, we view ourselves as teaching law. When we write that a contract requires consideration, we view ourselves as describing law. It might be argued that such a statement is shorthand for the proposition that a contract requires consideration under the law of most states, but as I will show below these statements are statements of law and are so intended. When a legal scholar teaches or 
writes that a contract requires consideration, he does not mean that he has checked the law of every state, or even that he relies on some scholar who has checked the law of every state. He means just what he says: that under the law of contracts-that is, the national law of contracts-a contract requires consideration. (Indeed, as shown in Part I, there are many cases where a categorical statement of a legal rule could not possibly mean that the rule has been adopted by every state, because many states will not have passed upon the issue.) Similarly, when bar examiners test applicants for admission to the bar on national law, they view themselves as giving a law examination.

But the question arises, to borrow H.L.A. Hart's characterization of criticism of the concept that international law is law, "We know that it is called law, but is it really law?"30

There are, of course, important competing concepts of what constitutes law. As discussed in Part I, in The Concept of Law, H.L.A. Hart developed the concept of the rule of recognition. Hart began with the thesis that a legal system consists of "a union of primary and secondary rules." ${ }^{31}$ Primary rules are rules of obligation that state how people are obligated to behave. ${ }^{32}$ Secondary rules are rules about establishing, changing, and applying primary rules. The most fundamental type of secondary rule is a rule of recognition. A rule of recognition is a rule that tells how to recognize that some other rule is a legal rule. It specifies "some feature or features possession of which by a suggested rule is taken as a conclusive affirmative indication that it is" a legal rule. ${ }^{33}$ It is a rule "for conclusive identification of the primary rules of obligation." "To say that a given rule is valid is to recognize it as passing all the tests provided by the rule of recognition ...." ${ }^{35}$ Thus a given rule is a valid legal rule if its pedigree can ultimately be traced to a source that is a source of law under a rule of recognition. In contrast, a given rule is a rule of recognition if but only if it is accepted by a relevant social group. (In reality, a rule of recognition will almost invariably consist of a cluster of rules. I will follow general usage by referring to such a cluster as if it were a single rule.)

A much different concept, developed by Dworkin, treats as law those principles that satisfy some designated standard of fit with

30. HART, supra note 2, at 215.

31. Id. at 79 .

32. Id. at $80-81$.

33. Id. at 94 .

34. Id. at 95 .

35. Id. at 103. Two other types of secondary rules are rules of change and rules of adjudication. A rule of change empowers an official to introduce new primary rules and to eliminate old ones. Id. at 95. A rule of adjudication empowers an official to determine au. thoritatively whether a primary rule has been broken. Id. at 97 . 
prior institutional decisions and best justify those decisions as a coherent whole in terms of political morality. For example, in Law's Empire, Dworkin states that "propositions of law are true if they figure in or follow from the principles of justice, fairness, and procedural due process that provide the best constructive interpretation of the community's legal practice ...." ${ }^{36}$

Another concept of law, which I develop in The Nature of the Common $\mathrm{Law}^{37}$ is that the law consists of the rules that would be generated at the present moment by application of the institutional principles of adjudication. I call this the generative concept. Under this concept, to determine the content of the law, courts and lawyers do not begin with doctrinal propositions and work backward to determine their validity, as they do under the concept of the rule of recognition. Rather, they begin with a set of institutional principles and work forward to generate legal rules. These institutional principles instruct the courts that in determining the law they should take account not only of doctrinal propositions promulgated by officials of the relevant jurisdiction, but also of the criticism and understanding of those propositions expressed in the professional discourse, doctrinal propositions established in the professional literature, and applicable social propositions. The rules generated by the interplay among those propositions under the institutional principles of adjudication are law.

For purposes of this Article, I will not argue for one of these concepts, but instead will take the concept of a rule of recognition as a postulate, partly because it is the most widely accepted concept of law; partly because, as Hart himself stressed, the rule of recognition is not a definition of law; ${ }^{38}$ and partly because important issues remain concerning the meaning and application of the concept, some of which are illuminated by the concept of national law. I will address

36. RONALD DWORKIN, LAW'S EMPIRE 225, 226, 240 (1986).

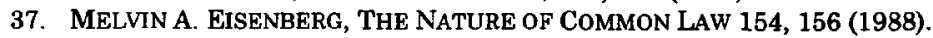

38. For example, Hart said:

[T] hough the combination of primary and secondary rules merits, because it explains many aspects of law, the central place assigned to it, this cannot by itself illuminate every problem. The union of primary and secondary rules is at the centre of a legal system; but it is not the whole, and as we move away from the centre we shall have to accommodate ... elements of a different character.

Though the idea of the union of primary and secondary rules has . . . virtues, and though it would accord with usage to treat the existence of this characteristic union of rules as a sufficient condition for the application of the expression 'legal system', we have not claimed that the word 'law' must be defined in its terms. It is because we make no such claim to identify or regulate in this way the use of words like 'law' or 'legal', that this book is offered as an elucidation of the concept of law, rather than a definition of 'law' which might naturally be expected to provide a rule or rules for the use of these expressions.

HART, supra note 2, at 99, 213. 
four such issues: (1) What social group must accept a secondary rule for it to constitute a rule of recognition? (2) How is it determined whether a rule has been accepted as a rule of recognition by the relevant social group? (3) Who are the lawmakers under the American rule of recognition? (4) Does the concept of the rule of recognition require that a rule be binding if it is to constitute a primary legal rule?

A. The Social Group That Must Accept a Secondary Rule for the Rule to Constitute a Rule of Recognition is the Legal Profession, Rather Than Simply Judges and Other Officials

If a secondary rule is to constitute a rule of recognition, it must be accepted by some social group. But what social group? Hart himself was somewhat ambiguous concerning just who must accept a rule if it is to constitute a rule of recognition. At some points he spoke about "the practice of judges, officials, and others," ${ }^{39}$ or about the presuppositions that lie behind "[s]tatements of legal validity made about particular rules in the day-to-day life of a legal system whether by judges, lawyers, or ordinary citizens." ${ }^{40}$ At other points, however, he spoke only of the acceptance of the rule of recognition by "officials," or as a rule of recognition as "existing only if it is accepted and practised in the law-identifying and law-applying operations of the courts." 42

Hart's views on this issue were either too broad or too narrow. At least in the United States, the relevant social group is neither society as a whole, on the one hand, nor judges and other officials, on the other. Instead, the relevant social group is the legal profession-that is, practicing lawyers (including government lawyers, such as attorneys general), legal academics, and especially, but not exclusively, the judiciary.

This approach is less inclusive than one in which the only social group whose acceptance counts is the society as a whole. A rule of recognition will not have requisite acceptance if it is actively rejected by the society as a whole. For the most part, however, the society as a whole is neither informed nor interested in what kinds of rules are legal rules, except in the most generalized way.

On the other hand, an approach that centers on the views of the legal profession is more inclusive than one in which the only social group whose acceptance counts is judges and other officials. Certainly acceptance of a rule of recognition by the judiciary is especially important, but judges are members of and participants in the wider

39. Id. at 109.

40. Id. at 108 .

41. Id. at 117 .

42. Id. at 256 . On Hart's ambiguity concerning this issue, see RAZ, supra note 3 , at 92 . 
legal culture, and form and reform their views of law as participants in that culture. Furthermore, if judges became seriously out of step with the general legal culture in regard to a rule of recognition, it is doubtful that the rule would long continue to have the requisite acceptance. Indeed, the integrity of the legal system would be seriously threatened if the judiciary were drastically out of step with the bar and legal academics concerning what constituted a legal rule. If that were to occur, the judiciary would be held in contempt by the very groups to whom they are most accountable. Moreover, at least in the United States, judges are, with rare exceptions, trained as practicing lawyers before assuming the bench, and it would be highly surprising if the views of law impressed on lawyers in their legal education and early careers were to be suddenly dropped when the lawyers put on robes. Finally, for most practical purposes the law is what practicing lawyers say it is; that is, to the extent that private or public actors plan or act on the basis of law, they will normally plan or act on the basis of what their lawyers tell them is the law. Accordingly, the views of practicing lawyers concerning what kinds of rules count as legal rules in rendering such opinions are of vital importance.

\section{B. Whether the Legal Profession Accepts a Secondary Rule as a Rule of Recognition Can Be Determined By Examining the Kinds of Primary Rules That Are Invoked by the Profession as Legal Rules in Resolving Legal Issues in General, and Deciding Cases in Particular}

Assuming the validity of the concept of the rule of recognition, how is it determined what kinds of rules constitute legal rules? To put this differently, how is the content of the rule of recognition determined? One method is to listen to what the profession says. A second method is to watch what the profession does. Under the second method, we begin by examining the kinds of primary rules that are invoked as legal rules by the legal profession in resolving legal issues in general, and deciding cases in particular, and then infer, from the invocation of those kinds of rules in that way, that the view of the profession is that under the rule of recognition such rules are legal rules.

That is a summary statement of a principle that I will call the "Invocation Principle." In the balance of this section, I will expand on this summary statement.

In full, the Invocation Principle has two parts.

The first part of the Principle is that any class of rules constitute legal rules if rules in that class are viewed as legal rules by the legal profession-practicing lawyers, legal academics, and especially, but not exclusively, the judiciary. The reason is simple. Once it is ac- 
cepted that a rule is a rule of recognition if it is viewed as such by the legal profession, then we must follow views of the profession in this regard wherever those views take us. Accordingly: (1) Any class of rules that are legal rules in the view of the legal profession are legal rules. (2) Such a class may be defined by any convention that the profession accepts at any given time. (3) Any such convention is or becomes part of the rule of recognition.

The second part of the Principle addresses the question, what is the operational test for whether rules in a given class are viewed as legal rules by the profession? The answer to that question is also simple: the test is whether in the view of the profession, and particularly the judiciary, it is proper to invoke rules in that class as legal rules, by which I mean to invoke rules in that class as legal rules of decision. Under the second part of the Principle, whether a given class of rules qualify as legal rules under the Principle is normally determined objectively, by observing the practice of the profession, and in particular the practice of the judiciary, to determine whether the profession, particularly the judiciary, invokes rules in that class as legal rules. However, although the legal status of the class of rules is determined objectively, by observing the practice, application of the Invocation Principle ultimately rests on the internal point of view that Hart made central-that is, on whether, in the internal view of the profession, particularly the judiciary, it is proper to invoke a class of rules as legal rules. ${ }^{43}$

We can infer the view of the profession on this question from two kinds of evidence. The first kind of evidence is a practice itself: in the absence of strong facts to the contrary, it is fair to infer that if members of the profession, especially judges, routinely follow a practice, they believe the practice is proper. The second kind of evidence is criticism, or more particularly the absence of criticism, in the literature of the legal culture-cases, law review articles, treatises, and the like. If the profession generally follows a practice of invoking a certain class of rules as legal rules, and there is no substantial criticism of the practice within the literature of the legal culture, it is fair to infer that the internal view of the profession is that the practice is proper.

To fully explicate the operation of the Invocation Principle, it is necessary to distinguish between doctrinal propositions and social propositions. By doctrinal propositions, I mean propositions that purport to state legal rules and are found in or can be derived from

43. The Invocation Principle is very similar to the methodology that Hart employed to justify characterizing international law as law. A major reason Hart gave for that characterization was that claims under international law are predominantly "couched .... [by] references to precedents, treaties, and juristic writings" rather than by reference to moral right or wrong. HART, supra note 2, at 228. 
sources that are generally regarded by the legal profession as expressions of legal doctrine. One group of doctrinal sources consists of official texts that are regarded as binding on a deciding court, such as constitutions, statutes, and certain kinds of precedents. A second group of doctrinal sources consists of texts that are promulgated by officials but are not binding on a deciding court, such as precedents in other jurisdictions and statutes that are applicable only by analogy. A third group of doctrinal sources consists of texts on the law authored by members and students of the profession, such as Restatements, treatises, and law reviews. I will refer to the second and third groups of doctrinal sources, taken together, as the national literature. It is in this literature that national law is to be found.

By social propositions, I mean all propositions other than doctrinal propositions. The types of social propositions most salient to modern Western law are moral norms, policies, and empirical propositions (such as propositions that describe the way in which people behave and institutions operate). In the balance of this Article, when I refer to social propositions I mean social propositions that are legally relevant and meritorious and that can properly be taken into account by a lawmaker.

For purposes of the Invocation Principle, the crucial difference between doctrinal and social propositions is that social propositions are invoked as reasons for legal rules, while doctrinal propositions are invoked as legal rules. So, for example, in the area of donative promises, one or more social propositions may be invoked to show why simple unrelied-upon donative promises should be legally unenforceable, while a doctrinal proposition is invoked to show that simple unrelied-upon donative promises are legally unenforceable. More generally, doctrinal propositions must be invoked to resolve legal issues and decide cases. In contrast, social propositions can never in themselves be utilized to decide cases or resolve other legal issues, unless they are either made into doctrines or made the basis of doctrines. For example, the moral proposition that promises should be kept cannot be invoked, as such, to decide a case. However, a court could determine that this moral proposition will be converted into the doctrinal proposition that all promises are legally enforceable, which will decide both the case at hand and all future cases to which the doctrine was applicable. Or, a court could determine that the moral proposition, when combined with policy propositions, will serve as the basis for a doctrinal proposition that certain kinds of promises are legally enforceable.

Accordingly, while social propositions cannot meaningfully be utilized to resolve legal issues and decide cases except in conjunction with doctrinal propositions that they justify, doctrinal propositions can be invoked to resolve legal issues and decide cases without invok- 
ing or even adverting to the social propositions that justify the doctrinal propositions. Indeed, it is just the fact that a proposition is properly invoked as a legal rule, rather than as a social reason for a rule, that marks out the proposition as a legal rule under the Invocation Principle.

National-law rules are legal rules because they are invoked in just this way. The doctrinal propositions that comprise national law are not invoked as reasons for legal rules; they are invoked as legal rules. $^{44}$ So, for example, a court faced with a relied-upon donative promise may-indeed, is highly likely to-invoke the rule of the $R e$ statement of Contracts that a relied-upon donative promise is enforceable as a rule of decision, without invoking the social propositions for the rule, and then apply that rule to the facts at hand to decide the case before it. The practice of the profession, and particularly the courts, in invoking rules of national law as legal rules of decision, just because they are rules of national law, is what makes national-law rules legal rules. As a result, when there is a national-law rule, then in the absence of a local binding precedent the nationallaw rule will often be treated in virtually the same way as such a precedent. For example, if there is no local binding precedent governing whether an acceptance that crosses with a revocation is effective on dispatch or on receipt, and the dispatch rule is established as national law, a court will typically invoke that rule in the same way as if the rule had been established in a local precedent. Indeed, national-law rules will often be invoked as law even if they lead to a result different from that established in local precedent, at least if the national-law rule is not wholly inconsistent with the precedent. Thus if a precedent of a state has established the rule that a donative promise is unenforceable, the courts of the state will nevertheless characteristically invoke the national-law rule that a donative promise is enforceable if relied upon. If a precedent of a state has established the rule that a firm offer is revocable, the courts of the state will nevertheless characteristically invoke the national-law rule that a firm offer is enforceable if relied upon. If a precedent of a state has established the rule that performance of a legal duty is not consideration, the courts of the state will nevertheless characteristically invoke the national-law rule that a promise to perform a legal duty is a

44. See John Henry Merryman, The Authority of Authority: What the California Supreme Court Cited in 1950, 6 STAN. L. REV. 613, 620 (1954):

[S]econdary authorities . . . can and do play a part in the total process which is not greatly different from that played by primary materials. It is possible for cases to be decided, rules of law to be stated, lines of decision begun and perpetuated, solely on the authority of a textual treatment having its origins outside the judicial or legislative process. ... [U]ltimately it becomes impossible to draw clear distinctions between primary and secondary authority except in terms of origin. 
consideration if the promise is part of a fair and equitable modification of the contract that gave rise to the legal duty.

Illustrations of the way in which national-law rules are invoked by the courts as legal rules of decision can be found in any state or regional reporter. I will give two examples here: Thieme $v$. Worst ${ }^{45}$ and Renner $v . K e h l .{ }^{46}$ Both Thieme and Renner are state-law cases that involve issues of mistake in contract law. In each case, the court decided the issues solely by invoking national-law rules, without in. voking either local law or the reasons for the national-law rules.

In Thieme $v$. Worst, ${ }^{47}$ the Thiemes purchased a tract of land from the Worsts. Ownership of the tract carried seven shares of water. The availability of these shares was an important consideration for the Thiemes, who intended to pasture animals and grow a garden. The tract had a system of water-delivery ditches in its southeast corner, and the Thiemes believed that the seven water shares were available through those ditches. The Worsts apparently believed the same thing.

It turned out that this belief was mistaken, because there was no system to conduct water to the ditches in the southeast corner. The Thiemes sued the Worsts for rescission and damages. The trial court found that the doctrine of mutual mistake applied to the transaction. ${ }^{48}$ Rather than granting the usual remedy of rescission, however, the trial court modified the contract to require the Worsts to provide a system that would deliver water to the southeast corner. ${ }^{49}$ The Thiemes wanted rescission, and appealed. The Idaho Court of Appeals affirmed, relying entirely on national law.

The court began with the issue whether the doctrine of mutual mistake was applicable, and invoked national law to show that it was:

The trial court found that the Thiemes would not have entered into the contract had they been aware of the water difficulties. Also, there was evidence showing that, during negotiations conducted through the brokers, Richard Worst rejected one offer made by the Thiemes and held out for a higher figure, contending that the water shares were worth the difference. Thus, we uphold the district judge's ruling that there was a mutual mistake. Both parties were mistaken "at the time [the] contract was made as to a basic assumption on which the contract was made. ..." RESTATEMENT (SECOND) OF CONTRACTS $§ 152$ (1979) (hereinafter cited as Restatement).

45. 745 P.2d 1076 (Idaho Ct. App. 1987).

46. 722 P.2d 262 (Ariz. 1986).

47. 745 P.2d at $1077-78$.

48. Id. at 1079.

49. Id. at 1080 . 
... [T] The Thiemes' view of the property would logically confirm their belief that seven shares of water were deliverable through an existing irrigation system. We are not persuaded that the Thiemes should bear the risk of the mistake under the rule stated in $\S 154$ of the Restatement. . . ${ }^{50}$

The court then turned to the issue of remedy and again invoked national law, this time to show that a remedy other than rescission could be granted for mutual mistake and was appropriate under the circumstances.

As noted in $\$ 152$ of the Restatement, where the mistake has a material effect on the agreed exchange of performances, the contract is voidable. The availability of water has been held basic to the lease or purchase of real property so that when water is not deliverable, rescission of the transaction is an available remedy. See, e.g., Fowler v. Uezzell, 94 Idaho 951, 500 P.2d 852 (1972) . . .; Blythe v. Coney, 228 Ark. 824, 310 S.W.2d 485 (1958) . . . However, rescission is not the exclusive remedy for mutual mistake; a court may consider other equitable remedies in fashioning a just result. Indeed, the avoidance rule of Restatement $\$ 152$ expressly recognizes that the materiality of the parties' mistake may be alleviated by other equitable relief. Correspondingly, $\S 158(2)$ of the Restatement acknowledges the power of an equity court to eliminate the effect of mistake by supplying a new term or otherwise modifying the agreement as justice requires, thus protecting the parties' reliance interests. ${ }^{51}$

In Renner $v . K e h l,{ }^{52}$ the Kehls were interested in the large-scale commercial cultivation of jojoba. The Renners held leases on 2,262 acres of unimproved desert land, which appeared to be ideal for the Kehls' purposes. The soil and climate were good, and both parties believed that sufficient water was available beneath the land to sustain jojoba production.

In June 1981, the Kehls executed a purchase contract to buy the Renners' leases for $\$ 222,200$, including $\$ 80,200$ down. Thereafter, the Kehls spent $\$ 229,649$ to develop the land, part of which went for

50. Id. at 1079-80. Section 154 reads as follows:

A party bears the risk of mistake when

(a) the risk is allocated to him by agreement of the parties, or

(b) he is aware, at the time the contract is made, that he has only limited

knowledge with respect to the facts to which the mistake relates but treats his limited knowledge as sufficient, or

(c) the risk is allocated to him by the court on the ground that it is reasonable in the circumstances to do 30 .

RESTATEMENT (SECOND) OF CONTRACTS $§ 154$ (1981).

51. Thieme, 745 P.2d at 1080 . Subsection 158(2) states that "[i]n any case governed by the rules stated in this Chapter, if those rules . . . will not avoid injustice, the court may grant relief on such terms as justice requires . . . ." RESTATEMENT (SECOND) OF CONTRACTS § 158(2).

52. 722 P.2d 262 (Ariz. 1986). 
drilling five test water wells. As a result of the drilling, the Kehls determined that the water aquifer underlying the property was inadequate for commercial development of jojoba. At this point the project was abandoned, and the Kehls sued to rescind the purchase contract.

The trial court found that the Kehls were entitled to rescission based on mutual mistake. It ordered the Kehls to reassign the lease to the Renners, and ordered the Renners to pay the Kehls $\$ 309,849$, consisting of the $\$ 80,200$ down payment and the $\$ 229,649$ cost of developing the property. Thus, Renner, like Thieme, involved both an issue of when a contract can be rescinded for mutual mistake and an issue of remedy.

The Arizona Supreme Court began by invoking national-law rules to show that the doctrine of mutual mistake applied:

The belief of the parties that adequate water supplies existed beneath the property was "a basic assumption on which both parties made the contract," Restatement (Second) of Contracts $\S 152$ comment $b$, and their mutual mistake "ha[d] such a material effect on the agreed exchange of performances as to upset the very bases of the contract." Id. comment a. The contract was therefore voidable and the respondents were entitled to rescission. ${ }^{53}$

The court then modified the remedy granted at trial, again on the basis of national-law rules:

[Although rescission for mutual mistake does not give rise to consequential damages, this does not mean] that the respondents [the Kehls] are entitled only to recover their down payment. When a party rescinds a contract on the ground of mutual mistake he is entitled to restitution for any benefit that he has conferred on the other party by way of part performance or reliance. Restatement (Second) of Contracts § 376. Restitutionary recoveries are not designed to be compensatory; their justification lies in the avoidance of unjust enrichment on the part of the defendant. D. Dobbs, Remedies $\S 4.1$ p. 224 (1973). Thus the defendant is generally liable for restitution of a benefit that would be unjust for him to keep, even though he gained it honestly. Id.; Restatement (Second) of Contracts $\S 376$ comment a. The issue we must now address is the proper measure of the restitutionary interest.

The first step determining the proper measure of restitution requires that the rescinding party return or offer to return, conditional on restitution, any interest in property that he has received in the bargain. Restatement (Second) of Contracts $\S 384(1)(a)$. In Arizona this includes reimbursement for the fair market value of the use of the property....

However, to avoid unjust enrichment the petitioners must pay the respondents a sum equal to the amount by which their prop-

53. Id. at 265. 
erty has been enhanced in value by the respondents' efforts. The Restatement (Second) of Contracts $\S 376$ provides that "[i]f [a party] has received and must return land . . . he may have made improvements on the land in reliance on the contract and he is entitled to recover the reasonable value of those improvements. . . . The rule stated in this section applies to avoidance on any ground, including . . . mistake. . . " comment $a$. The reasonable value of any improvements is measured by "the extent to which the other party's property has been increased in value or his other interests advanced." Restatement (Second) of Contracts $\S 371(b)$. Thus the petitioners must pay to the respondents that amount of money which represents the enhanced value of the land due to the respondents' development efforts. In short, the respondents are entitled to their down payment, plus the amount by which their efforts increased the value of the petitioners' property, minus an amount which represents the fair rental value of the land during their occupancy. They are not entitled to the $\$ 229,649.84$ expended upon development, because that would shift the entire risk of mistake onto the petitioners, which is incompatible with equitable rescission. ${ }^{54}$

There are undoubtedly thousands of cases like Thieme and Renner, in which all or some significant part of the decision turns on the invocation of national-law rules as rules of decision. Of course, the majority of cases do not turn on national law. However, my point is not to show that national law is the predominant form of law in the United States, but only to show that it is a form of law in the United States.

Not every rule found in the national literature will be viewed by the profession as a legal rule. National law consists of rules that are generally established in that literature, or are established in one or more weighty sources, such as a Restatement, a line of national cases, or a treatise that the profession regards as authoritative, and not seriously contradicted by others.

Sometimes, there may be no clear national-law rule on an issue in an area of national law. For example, there are two or even more rules in the national literature concerning a landowner's liability in tort to a person injured on his property. However, there also may be conflicting rules in local law or federal law. For example, different intermediate appellate courts in a given state may formulate different rules on when contract damages are sufficiently certain, and different federal circuit courts may formulate different rules on whether a person who trades on inside information has acted with scienter. That does not lead us to say that there is no state or federal law. It is true that in these cases there is an official organ, the highest court in

54. Id. at 266-67. 
the relevant jurisdiction, that can resolve the difference between appellate courts. However, international law may include divergent or even contradictory strands, but we do not for that reason say there is no international law, even though in that case typically there is no official organ that can conclusively resolve such differences. The absence of a clear national-law rule on a given issue in a national-law area is no more embarrassing to the status of national law as law than the absence of a clear rule on a given issue is embarrassing to the status of state, federal, or international law as law.

Furthermore, the extent to which there is discord in national law will typically depend on whether the focus is on the core or the penumbra of an area. In most issues in national-law areas, like contracts and torts, the national-law rule is clear, and where there is discord it is only at the penumbra. Thus Martin Shapiro, looking at tort law from the perspective of a political scientist, drew the conclusion that "[w]hat makes tort so interesting for the study of organizational policy-making . . . is that there are not fifty-two bodies of tort policy but in a very real sense a single body of . . . tort law that runs throughout ... the United States, with local variations to be sure, but with a remarkably uniform core. ${ }^{p 5}$

The characterization of national law as law rests principally on an application of the concept of the rule of recognition, mediated through the Invocation Principle. This characterization is also supported, however, by the methodology that Hart employed to justify the characterization of international law as law. Hart based that characterization on what he called analogies of function and content between municipal law (that is, domestic law) and international law.

The analogies of function that Hart drew concerned the way in which claims under international law are couched:

[The moral pressure by which social morality is primarily sup. ported] consists not of appeals to fear or threats of retaliation or demands for compensation, but of appeals to conscience, made in the expectation that once the person addressed is reminded of the moral principle at stake, he may be led by guilt or shame to respect it and make amends.

Claims under international law are not couched in such terms though of course, as in municipal law, they may be joined with a moral appeal. What predominate in the arguments, often technical, which [nations] address to each other over disputed matters of international law, are references to precedents, treaties, and juris-

55. Martin Shapiro, Decentralized Decision-Making in the Law of Torts, in PoLITICAL Decision-MAKING 44, 50 (S. Sidney Ulmer ed., 1970); see also Stephen D. Sugarman, Should Congress Engage in Tort Reform?, 1 MICH. L. POL'Y REv. 121, 127 (1996). 
tic writings; often no mention is made of moral right or wrong, good or bad. Hence the claim that the Peking Government has or has not a right under international law to expel the Nationalist forces from Formosa is very different from the question whether this is fair, just, or a morally good or bad thing to do, and is backed by characteristically different arguments. ${ }^{56}$

The analogies of content "consist in the range of principles, concepts, and methods which are common to both municipal and international law, and make the lawyers' technique freely transferable from the one to the other. Bentham, the inventor of the expression international law', defended it simply by saying that it was 'sufficiently analogous' to municipal law."57

Both of these analogies also hold between national law, on the one hand, and state and federal law, on the other. As in the case of state and federal law, rules of national law are invoked-"couched," as Hart put it-as claims of law, not of morality or policy. And the "range of principles, concepts, and methods" in state and federal law, on the one hand, and national law, on the other, "make the lawyers' technique freely transferable from the one to the other." Following Hart, therefore, national law is law not only under the concept of the rule of recognition, as mediated through the Invocation Principle, but also because national law, like international law, is "sufficiently analogous"' to state and federal law in function and content to have the status of law. ${ }^{58}$

The argument so far in this section has rested on positive-law grounds; that is, on the grounds that national law is law on the basis of the concept of the rule of recognition, as mediated by the Invocation Principle, and also by analogy to state and federal law. However, normative reasons also support treating national law as law.

First, a major function of law is to allow private actors to engage in reliable planning and coordination. National law facilitates those functions because it supplements local law, which is often sparse in given areas, with a rich network of legal principles and rules that lawyers can invoke when local law has not spoken to a given issue.

56. HART, supra note 2, at 228.

57. Id. at 237.

58. I might, but do not, claim that national law is law on analogy to international law. I do not make that claim because international law is binding while national law is not. That distinction might plausibly be considered sufficient to make such an analogy unconvincing (although I will show in Part III.C. that the fact that a rule is not binding does not mean that it is not a legal rule). Therefore, I claim only that the methodology that Hart employed to justify the characterization of international law as law also justifies the characterization of national law as law. 
Second, national law facilitates the growth of law by providing a legal source of legal change. So, for example, when courts began deciding that donative promises were enforceable if relied upon, notwithstanding existing local-law rules that donative promises were unenforceable, they were able to draw on legal rules as well as social propositions to support that conclusion. The same thing is true when courts began deciding that bargains could be reviewed for unconscionability, notwithstanding local-law rules that bargains are enforceable according to their terms without regard to fairness; when courts began holding that notwithstanding a local legal-duty rule, a modification of a contract in which the only consideration on one side is a promise to perform a preexisting duty is enforceable if the modification is fair and equitable; and so forth. The ability to draw on the resources of national law to support changes in local law helps reduce the transition costs of change, partly because national law puts the profession on notice that the law has already changed.

\section{A Rule Can Be a Legal Rule Even Though it is Not Binding}

I characterize national law as law. However, I do not claim that the rules of national law are binding. Accordingly, it is implicit in this characterization that a rule can be a legal rule even if it is not binding.

I could argue, in support of this characterization, that many rules that are unquestionably legal rules are not binding in any rigorous sense of that term. For example, common law rules are not binding in any rigorous sense. Presumably, the test for whether a rule is binding, under positivism, is the same as the test Raz lays down for whether a dispute is "regulated," namely, that the rule is clear and cannot be changed by the court. Presumably too, this test is contentindependent; that is, under this test whether a rule is clear and cannot be changed by a court depends on the way in which the rule was adopted-to put this differently, on the source of the rule-not on the content of the rule. In fact, however, very few common law rules satisfy these conditions.

To begin with, a court has power to overturn or change any common law rule. Of course, this power is subject to explicit or implicit institutional principles concerning when overturning or change is proper, but the application of those principles is almost entirely based on the content of the rule. If a common law rule is substantially congruent with the rule that would be best as a matter of social morality, social policy, and experience (hereafter, "social propositions"), the rule should be retained and applied even if it is not the best rule, because the social value of stability of doctrine will outweigh the slight social gain from changing or overturning the rule. 
On the other hand, if a common law rule is substantially incongruent with social propositions, the significant social gain from overturning or changing the rule will outweigh the value of stability of doctrine, and the court should overturn or change the rule.

It is true that pure overruling does not frequently occur, but neither is it uncommon, and in any event the point here is not an issue of frequency. Rather, the point is that any common law rule can be overturned or changed if it is substantially incongruent with social propositions. Furthermore, although pure overruling is not frequent, other methods of overturning and changing common law rules are common. For example, a court can properly interpret precedents in two very different ways: by emphasizing what the precedents said or what the precedents did. Accordingly, a court can properly transform a rule established in the precedents, without formal overruling, by "reinterpreting" the precedents on the basis of their facts. This method was utilized, for example, in MacPherson v. Buick Motor Co. ${ }^{59}$ There Cardozo transformed a previously well-settled rule, that a manufacturer who was negligent in producing a product was liable only to the immediate buyer unless the product was of a type that was "imminently" or "inherently" dangerous, into a straightforward negligence rule, under which a negligent manufacturer was liable to any person who would be foreseeably injured as a result of the negligence. Like overruling, the method of transformation is wholly content-dependent; it will be employed only when the rule stated by the precedents is substantially incongruent with social propositions.

Using an even more common process, a court can properly change a rule by modifying the rule through the process of distinguishing the precedents in which the rule is stated. The institutional principles that govern this process are also content-dependant: where a rule is substantially incongruent with social propositions, the courts properly can and often will modify the rule by adopting an exception that is inconsistent with the basic rule.

In short, courts have both formal and substantive power to not apply the common law rules they have made, because instead of applying the rule the court can change or overturn it by such processes as overruling, transformation, or modification through distinction or interpretation. Furthermore, the institutional principles that determine when it is appropriate to change or overturn a common law rule through any of these processes are content-dependent, that is, they depend wholly or almost wholly on the extent to which the rule is congruent with social morality, social policy, and experience. 
I have discussed these and cognate issues at length in The Nature of the Common Law, ${ }^{60}$ and therefore will not elaborate them here. For present purposes, the basic point is that in the United States a court that makes a common law rule is not bound by the rule in any rigorous sense of that term, because the court is not required to apply the rule unless the content of the rule is substantially congruent with social propositions. ${ }^{61}$ Accordingly, if rules are legal rules only if they are binding in the sense that that they are clear and cannot be changed by the courts, very few common law rules would qualify as legal rules.

Nevertheless, I will not rest the thesis that a nonbinding rule can be a legal rule on the proposition that in the United States common law rules are not in any rigorous sense binding on the courts that make them, because common law rules are binding in two weak senses.

First, common law rules are binding in the weak sense that a court that does not follow a common law rule that it made is subject to criticism unless the rule is substantially incongruent with morality, policy, and experience. This kind of criticism differs from the kind of criticism that can be made of a court that does not follow national law.

Second, common law rules that are made by superior courts are typically binding on inferior courts. This sense of binding is also weak, partly because it depends on the existence of inferior courts, partly because even inferior courts can and do have power to change a rule by the process of distinguishing, and partly because even if a common law rule is binding on an inferior court it is not binding in any rigorous sense on a litigant, who can appeal from the inferior court to a court that does have power to change or overturn the rule.

Accordingly, at least for present purposes I will accept that a common law rule is binding in a weak sense and that national law is not binding even in a weak sense. Therefore, my argument in support of the claim that a rule can be a legal rule even though it is not binding rests on two different bases.

To begin with, considering the very weak nature of the meaning of binding in the common law, any concept of law that turned to a significant extent on whether a rule was binding would swing on a very weak hinge.

60. EISENBERG, supra note 37 .

61. Much the same holds true of rules that consist of statutory or constitutional interpretations; that is, although the courts cannot change or overturn a constitutional or statutory text, they can change or overturn the interpretation of such a text in earlier precedents. For economy of exposition, I will not discuss this issue separately. 
Next, if the rule of recognition is taken as a postulate, and if it is accepted that a secondary rule is a rule of recognition if it is viewed that way by the profession, then we must follow the views of the profession wherever they lead us, rather than laying down a priori conditions-such as whether a primary rule is binding-as to what rules of recognition the profession may adopt. Accordingly, any class of primary rules, including rules that are not binding, are legal rules if they constitute legal rules under whatever criteria are contained in a secondary rule that is viewed by the profession as a rule of recognition. A claim that a primary rule must be binding if it is to be a legal rule is therefore inconsistent with the concept of the rule of recognition, which includes no such a priori requirement. (This point holds even if a rule of recognition must be accepted by judges and other officials, rather than the legal profession.)

A strong example of this point-stronger even than national law, because much more widespread-is the position of judicial opinions in civil law. In civil-law systems, it is almost invariably a rule, either explicit or implicit, that the rules in a judicial opinion are not binding. However, in most civil-law systems the rules established in judicial opinions count as law in almost the same way that such rules count as law in common law countries.

Under German law, for example, precedents other than those of the Federal Constitutional Court are not binding. ${ }^{62}$ Nevertheless, precedents play a vital role in German law. For example, Alexy and Dreier report that precedents are cited in ninety-five percent or more of cases in the highest courts. ${ }^{63}$ Moreover, they point out, "[t]he fact that following ... precedent usually is not combined with [argument based on substantive considerations other than the precedent] shows that precedents have a force of their own. This is underscored by the fact that a lawyer neglecting precedents of higher courts may be liable in damages to his clients." 64

Reinhard Zimmerman elaborates the role of judicial opinions in German law as follows:

[The Civil Code] is today enveloped by thick layers of case law which anybody who wishes to apply the law has to be thoroughly familiar with. Drafting mistakes and internal inconsistencies were discovered in the code. ... Entirely new and unforeseen legal problems had to be solved: What are the legal consequences of artificial insemination? Can the birth of a child conceivably be regarded as a damaging event? ... Changed societal mores and evaluations had

62. See, e.g., Robert Alexy \& Ralf Dreier, Precedent in the Federal Republic of Germany, in INTERPRETING PRECEDENTS: A CoMParative STUdy 17, 26-27, 32 (D. Neil MacCormick \& Robert S. Summers eds., 1997).

63. Id. at 23 .

64. Id. at 31 (citation omitted). 
to be accommodated. . . . Unjustified enrichment, delictual liability, the law of damages: areas such as these, where the code only provides some general principles, have become pockets of a typical case-law jurisprudence.

But the courts have done much more. They have introduced entirely new legal institutions of which we find, at best, one or two scattered points of departure, sometimes not even the faintest hint, in the code. The German equivalent of frustration of contract ... was formulated, initially, in response to the problems posed by the consequences of the First World War on the performance of long-term contracts and has become an established feature of the German legal landscape, even though the draftsmen of the code had rejected its predecessor of the pre-code ius commune period .... .

Culpa in contrahendo [has been installed] in the grey area between contract and delict, and positive malperformance has been introduced as a specific type of breach of contract, supplementing the (rather awkward) system of remedies provided by the code. Often these new institutions have been designed to circumvent certain provisions of the code which have turned out to be inappropriate or inconvenient. ...

The famous "general clauses" . . . of the [Civil Code] have of course, provided the most convenient space for judicial lawmaking. In the process however, they have been taken far beyond the scope of application originally allotted to them. The standard of 'good faith,' for instance, appears only in a seemingly rather marginal provision ( $\$ 242$ ), where it relates specifically to the manner in which an obligation has to be performed. Soon, however, the courts seized upon the rule and converted it into a provision governing, and transforming, the whole of the German law of contract $\ldots 6^{65}$

Thus it is impossible to understand German law without taking account of rules set out in judicial opinions, despite the fact that those rules are not binding. Generally speaking, that is also true of other civil law jurisdictions. As summarized by Martijn Hesselink:

[I]n the course of the last century it became ... obvious that courts effectively do and must create new laws. Thus it became normal to speak of a change in the courts' direction or policy ... and courts do now frequently formulate general rules or principles .... Moreover, it is now widely accepted that la jurisprudence should be regarded as a source of law (sometimes in less straightforward language referred to as "unwritten law", as opposed to the written law in the codes, which is "found" by the courts). Finally, in most

65. Reinhard Zimmermann, An Introduction to German Legal Culture, in InTRODUCTION TO GERMAN LAW 1, 16-18 (Werner F. Ebke \& Matthew W. Finkin eds., 1996). 
European countries we now speak openly of our (highest) courts' task as a creator of law ...66

There are many nuances (in part made necessary by the rule that precedents are not binding in the civil law), but the main, and fairly limited, functional difference between the rules established in judicial opinions in common law and civil law countries is that when common law rules are formally overturned they are said to be overruled, while when civil law rules are overturned they are not said to be overruled; that it may be somewhat easier to overturn civil law rules than it is to overturn common law rules; and that there may be no no need to distinguish cases in the civil law. These differences are simply not enough to be significant in the concept of what constitutes law.

The actual working of the common law in the United States shows that any concept of law that made the definition of law turn in part on bindingness would swing on a very weak hinge. The actual working of the civil law takes us a step further. The massive amount of law found in the judicial opinions in civilian jurisdictions shows that any concept of law that turns in part on bindingness completely lacks explanatory power and an empirical foundation. In short, if we seek a concept of law that is based on actual practices and conventions, rather than on a priori convictions, then both common law and civilian legal systems show that a rule may be a legal rule even though it is not binding.

\section{In the United States, Law is Made Not Only by Judges and Other Officials of the Deciding Jurisdiction, but Also by the National Judiciary, Legal Scholars, and Professional Institutions}

Another implication of the concept of national law is that in the United States law is made not only by judges and other officials of a deciding jurisdiction, but also by the national judiciary, legal scholars, and professional institutions (in particular, the American Law Institute). Some stands of positivism explicitly or implicitly posit a very restricted set of lawmaking participants, that is, judges and other officials of a deciding jurisdiction. However, just as the content of the rule of recognition in the United States depends on the views of the legal profession, not simply on the views of judges and other officials, so too does the legal profession, not simply judges and other officials, participate in lawmaking. Law in the United States is not just an entity that is handed down by officials. Rather, it is a product of an ongoing conversation within the profession-between judges in

66. Martin W. Hesselink, The New European Legal Culture 12 (2001). 
all jurisdictions, between scholars, within professional institutions, and among all these groups.

\section{CONCLUSION}

There is a body of national law. It is made, not by officials of a deciding jurisdiction acting in that capacity, but by the legal profession, including the national judiciary, legal scholars, and professional institutions, principally the American Law Institute. If the concept of the rule of recognition is taken as a postulate, national law is law primarily because the rules of national law are invoked by the legal profession, including the judiciary, as legal rules of decision. Following Hart's methodology, national law is also law by analogy to state and federal law.

The concept of national law is significant for several reasons.

First, it is important to understand the tools utilized in the practice of law, in the teaching of law, in legal scholarship, and in judicial decisionmaking, and national law is one such tool. Because national law is law, American legal scholars can meaningfully write about and teach national law, and the American Law Institute can meaningfully help make law. Because law students are educated in national law, practicing lawyers and judges will have internalized both the substantive rules of national law that they learned in law school and the institutional principle that rules established in national literature are law.

Next, it is important to understand the techniques by which uniformity in law can be achieved, and national law is one such technique.

Finally, national law exemplifies four important principles concerning the meaning, application, and scope of the concept of law: (1) The social group that must accept a secondary rule for the rule to constitute a rule of recognition is the legal profession, rather than simply judges and other officials. (2) Whether the legal profession accepts a secondary rule as a rule of recognition can be determined by examining the kinds of primary rules that are invoked by the profession as legal rules in resolving legal issues in general, and deciding cases in particular. (3) A rule can be a legal rule even though it is not binding. (4) In the United States, law is made not only by judges and other officials of the deciding jurisdiction but also by the national judiciary, legal scholars, and professional institutions. 
HeinOnline -- 29 Fla. St. U. L. Rev. 1264 2001-2002 